\title{
Ikus-entzunezko teknikak (ist) irakastea: etorkizuneko ikus-entzunezkoetako profesionalen hezibidea
}

\author{
Beatriz Zabalondo Loidi \\ Vanesa Fernandez Guerra \\ Estibaliz Alonso Ruiz de Erenchun \\ Aintzane Pagadigorria Ruiz \\ Ikus-Entzunezko Komunikazioa eta Publizitatea Saila \\ Gizarte Zientzien eta Komunikazio Fakultatea \\ Euskal Herriko Unibertsitatea (UPV/EHU)
}

DOI: $10.1387 /$ tantak.16334

GAKO-HITZAK: Ikus-entzunezko Produkzioa eta Errealizazioa. Irrati/ TBko profesionalak heztea. Ikaskuntza kooperatiboa. Proiektuetan oinarritutako ikaskuntza. Hezkuntza unibertsitarioa.

\section{SARRERA}

Artikulu honen asmoa unibertsitate mailako esperientzia berritzaile bat aurkeztea da, goi mailako irakaskuntzan aritzen diren beste profesional batzuentzat adibide baliagarria gerta daitekeelakoan, batik bat ikus-entzunezko ikasgai teknikoak irakasten dabiltzanentzat. Zehazki, gai honetan jarriko dugu arreta: Ikus-entzunezko Sormen Teknikak ikasgaiaren (IST) ikaskuntza nola eta zergatik oinarritu dugun POI metodologian, betiere gure unibertsitateko IKD markoaren barruan, alegia, metodologia kooperatibo eta dinamikoetan. Esan gabe doa metodologia horretan ikaslea dela ikaskuntza prozesuaren ardatza eta IKDk, bai ikasleari, bai irakasleari, lan eredu aktiboetan inplikatzea eskatzen diola. Hala, beraz, lerrootan aurkeztuko dugun IST ikasgaiaren planifikazioak bi alderdi hauetan jarri nahi du indarra: ikasleak lankidetza lanean trebatzea eta gure inguruko gizartearen premietara moldatzen ikastea.

Europako hainbat unibertsitatetan ezarri dira metodologia aktiboak goi mailako ikaskuntzan, eta agerikoak dira emaitza onak (Guisasola eta Garmendia, 2014, 32 or.). Euskal Herriko Unibertsitatea bera ere Europako unibertsitateen eredupean murgilduta dago (Fernandez eta Alkorta, 2014, 
13 or.), eta dagoeneko bost urte igaro dira, Kalitate eta Berrikuntzaren Errektoreordetzak bultzatuta eta HELAZ Zerbitzuaren laguntzaz, ikaskuntzarako metodologia aktiboen teknikak ezartzea erabaki zuenetik: Ikaskuntza Kooperatiboa (IK) eta Arazoetan Oinarritutako Ikaskuntza (AOI), eta horren garapena den Proiektuetan Oinarritutako Ikaskuntza (POI). Euskal Herriko testuinguruan, metodologia horiek ikaste-irakaste prozesuen iraultza ekarri dute, eta, are gehiago: ikaskuntza bide berrietan murgiltzeak Europako kredituen sistemara (ECTS, European Credit Transfer System) egokitzea erraztu du.

Metodologia aktiboetan oinarritutako ikaskuntzak guztiz eraldatu du ohiko ikaskuntza, eta lan egiteko era guztiz bestelakoak barneratu dira. Hala, AOI metodologiak ikaskuntzaren hasieran arazo bat planteatzea esan nahi du; ikasleek arazoa ebazteko behar dituzten ikaskuntza premiak identifikatu, eta, azkenik, arazoari heltzen diote. Arazoaren planteamendutik eta ebazterainoko bidean, modu kooperatiboan lan egiten trebatuko dira ikasleak: talde txikietan (ikasketa kooperatiboaren teknikak baliatzen dira) ikasketa esperientzia partekatzen dute, eta, aldi berean, zeharkako gaitasun eta trebeziak lantzen eta garatzen dituzte. Gainera, prozesuan zehar, jarrera eta balioen gaineko behaketa eta gogoetak gailentzen dira ikaskuntzaren dinamikan, eta ikaskuntza ekintzaren ardatz bilakatzen dira, metodologia konbentzionaletan ez bezala.

Euskal Herriko Unibertsitateak garatutako eredu pedagogikoa - IKD izenekoa, Irakaskuntza Kooperatibo eta Dinamikoa-, operatiboki abian jarri zuen 2012-2017 Plan Estrategikoan: eredu propio, kooperatibo, eleaniztun eta inklusiboa da, eta ikasleak beren ikaskuntzaren jabe egiten ditu, beti ere formakuntza integral, malgu eta gizartearen beharretara egokitua helburu duela. IKD ereduak honako galdera ardatz honi erantzun asmo du: nola landu behar da ikaskuntza-irakaskuntza binomioa XXI. mendeko Euskal Unibertsitatean?

Ikus-entzunezko Komunikazioko Graduari dagokionez, ikaskuntza planak honako xede hau jasotzen du: ikaslea ikus-entzunezkoen arloko profesional aditua bihurtzea; hau da, informazioaren, komunikazioaren zein ikerketaren arloan profesional gaitu eta ongi trebatuak heztea.

Komunikazio multimedia eta ikus-entzunezkoak bizi gaitu, eta UPV/ EHUk garbi ikusi du Komunikazioko edozein arlotako ikasleek ikus-entzunezko trebakuntza jaso behar dutela - oinarrizko kontzeptu eta teknikak - . Horregatik, Komunikazioko graduetako lehen mailako ikasle guztiei eskaintzen zaie Ikus-entzunezko Sormen Teknikak ikasgaia, berdin dio zein gradu egingo duten: Kazetaritza, Publizitatea eta Harreman Publikoak edo Ikus-entzunezko Komunikazioa. Hiru graduetan oinarrizko ikasgaia da (6 ECTS) IST ikasgaia; lehen mailako bigarren lauhilekoan irakasten da, astean bi orduko eskola magistralekin eta beste bi orduko praktikekin; gainera, eskolaz kanpoko jarduerak osatzeko, astean beste hiru ordu daude aurreikusita. Guztira, hamabost-hamasei aste irauten du lauhilekoak. 


\section{IKUS-ENTZUNEZKO KOMUNIKAZIO IKASKETAK EUSKAL HERRIKO UNIBERTSITATEAN}

Ikus-entzunezko Komunikazio ikasketek ibilbide nahiko luzea dute Euskal Herriko Unibertsitatean. Ondo jakina denez, garai bateko Kazetaritza, Publizitate eta Harreman Publikoak eta Arte Ederretako lizentzietako egitarau dozenteetan hainbat ikasgai zeuden lotuta irudiaren azterketarekin eta ikus-entzunezko produktuen sorrerakin. Baina Ikus-entzunezko Komunikazioa, titulazio beregain gisa, 1995/1996 ikasturtean abiatu zen Gizarte Zientziak eta Komunikazio Fakultatean, lehenago Informazio Zientzien Fakultatea zen hartan.

Ia bi hamarkada igaro dira, eta, harrezkero, titulazioak hainbat erreforma eta eraberritze jasan ditu. Gaur, 1999an ezarri zen Boloniako Ikasketa Planaren barruan dago. Urte hartatik hona, Fakultate honek numerus claususa ezarri behar izan du ikus-entzunezko ikasketetan (75 ikasle gehienez), eta sarbideko notak ere unibertsitateko batez bestekotik gorakoak ditu (2014/2015ean: 8,72; 2015/2016an: 8,684). Komunikazioaren sektorean gertatzen ari diren aldaketen isla da, halaber, urtetik urtera ikasle gehiagok eskatzea Ikus-entzunezko Komunikazioko Graduan sartzea EHUn.

Europako Goi Hezkuntza Esparrura (EGHE) egokitzeak ikasketa plan berria ezartzea ekarri du, eta, hala, besteak beste, lizentziatik gradurako jauzia ematea. Horrek ikasketen filosofia aldaketa ekarri du, eta metodologia pedagogikoan nabaritu da gehien-gehien: ikaslearengan ardaztutako metodologia aktiboa, eta etorkizuneko profesionalari lanbidean egoki moldatzeko gaitasun-trebetasunak irakasteko bideratu baita egun.

Europako eremuari dagokionez, ANECAk prestatutako Komunikazioaren Liburu Zurian (2005, 37-99 or.) jaso zenez, Europako Goi Hezkuntza Esparruko (EGHE) 29 herrialdeetatik gutxienez 12tan eskaini ziren komunikazio ikasketak 90eko hamarkadan eta 2000ko hamarkadaren hasieran. Bestela esanda, Boloniako hitzarmenak sinatutako estatuetan, unibertsitateek Humanitateetako eskaintza nagusietakoa izan dute komunikazioa: Alemania, Erresuma Batua, Eslovakia, Finlandia, Frantzia, Grezia, Herbehereak, Italia, Lituania, Portugal, Suedia eta Txekiar Errepublika.

Euskadiko Ikus-entzunezko Sektorearen Liburu Zurian (2003), Eusko Jaurlaritzak berariaz sortutako sektoreko erakundeek osatutako diagnostikoaren ondorioak jaso ziren, eta arloko industriaren garrantzi ekonomikoa ez ezik, sektoreak herrialdearen garapenean duen interes kultural eta sinbolikoa ere azpimarratu zen. Ikus-entzunezko sektorea Euskal Herriko kultur eta edukizko industrien sistemako osagaia da: ekonomian duen eraginaz landa, ezin da ahaztu komunitatearen kultura zelai-joko horretan jokatzen dela; beste era batera esateko, herrialdearen kultur etorkizuna dago jokoan. Ezagutzaren eta informazioaren gizartean, ikus-entzunezkoen sektoreak ezinbesteko rola betetzen baitu kulturek gizon-emakumeen premietara egokitzeko zereginean. 
Liburu Zuriak euskal ikus-entzunezkoen sektoreak dituen arazoetan ere pausatzen du begirada, eta aurre egiteko proposamenak jorratzen ditu; hala, sektoreko profesionalen trebatzea eta birziklatzeko beharra nabarmentzen ditu. Ikus-entzunezkoen sektorean ezinbestekoak dira ekipoak eta azpiegiturak, baina honako ezaugarri hauek ezartzen dute benetako aldea: ezagutza, eskarmentua, kalitatea, egunean egotea, erkatzea, giza baliabideen kopurua eta prestakuntza sarea.

Hainbat eraldaketa gertatu dira azken urteetan ikus-entzunezkoen sektorean, besteak beste tradizionalki ezagutu diren hedabideen arteko - eta haien hizkuntza eta lanbideen arteko - mugen desagertzea, gainditzea. Gure gizarte inguruneari dagokionez, Larrañagak (2012) eta haren lankideek azaldu digute EITB Taldeko hedabideen eta euskarrien konbergentzia nola bideratu den. Konbergentziaren fenomenoak, batetik, ikusentzunezkoen izaeraren eta eremuaren lausotzea ekarri du, eta, bestetik, sektorearen garapena eta formatu eta lan molde berrietan aritzeko aukerak zabaltzea. Gaur egun, ikus-entzunezkoena ez da hedabide jakin bat; aitzitik, hedabideen bat-hartze emankorrak ekarri duen ingurune multimediara hedatzen da.

\section{IKUS-ENTZUNEZKO KOMUNIKAZIOKO GRADUAREN HELBURUAK: METODOLOGIA AKTIBOEN BITARTEZ, SEKTOREAN ARITZEKO PROFESIONALAK TREBATZEA}

Esan gabe doa, bada, EHUko Ikus-entzunezko Komunikazioko Graduan trebatu nahi ditugun profesionalek ikus-entzunezko programa eta proiektuak sortzeko eta kudeatzeko gai izan behar dutela, gure kulturaren, hezkuntzaren, gizartearen eta ekonomiaren sektoreetan garatzeko eta eragiteko. Gainera, ikus-entzunezko produktuak garatzeko prestatuta egongo dira: hasi edukien sortzetik, eta haien alderdi estetiko, narratibo eta teknikoen diseinatze eta gauzatzeraino.

Graduko lau urteko ikasketa hauen bitartez, kultur industrien eta komunikazioaren arloan kudeatzaile izateko gaitasun eta ezagutzak ere garatuko ditu ikasleak. Ikus-entzunezko komunikazioari eta hizkuntzari buruzko teoria, metodo eta arazoez ikasitakoa baliagarria izango du, halaber, nola baliozko iritziak emateko lanbidean, hala arlo horretako irakasle bilakatzeko.

Honela laburbil daitezke Ikus-entzunezko graduaren helburu orokorrak:

- Ikasleei ikus-entzunezkoen arloan kritikarako, analisirako eta gogoetarako gaitasunak sustatzea, gure inguruko ikusizko komunikazioaren forma, prozesu eta joeren ezagutza tekniko-estetikoak landuz.

- Ikus-entzunezko ikasleak ikus-entzunezko garrantzitsuenen ezagutza oinarrizko eta jeneralistetan trebatzea, baita errepresentazio iko- 
niko eta akustikoetan eta horiek izan duten bilakaeran ere. Halaber, oso garrantzitsua da ezagutza horien dimentsio espaziala.

- Ikasleek ikus-entzunezkoen sortze eta banatze prozesuetan - beren faseei jarraiki - ezagutza zehatza izatea, baita prozesu horietan subjektu direnen arteko elkarrekintzetan ere: egile, erakunde, enpresa, hedabide, euskarri eta hartzaileak. Formakuntza horrek ikus-entzunezko komunikazioaren arloan erabaki sortzaile eta profesionalak hartzeko gaituko ditu ikasleak, eta, halaber, sektoreko enpresetan baliabide teknologikoak eta giza baliabideak kudeatzeko.

- Ikus-entzunezko Komunikazioko Gradua amaitzen dutenerako, ikasleek ikus-entzunezkoetako ikerketa, garapen eta berrikuntzako metodologia eta kontzeptuak ezagutuko dituzte.

- Ikus-entzunezko Komunikazioko graduatuek gai izan behar dute argi eta zehatz komunikatzeko, erkidegoko bi hizkuntza ofizialetan. Nazioarteko beste hizkuntzaren bat jakiteak ere - esate baterako, ingelesak - bide asko irekiko dizkie.

\subsection{KOI, AOI, POI eta ikaskuntza kooperatiboa}

Etorkizunean, ikasketak amaitu eta lanera jauzi egindakoan, zinemaren, telebistaren eta ikus-entzunezkoen munduan mugitu beharko dira gure ikasle egresatuetako asko. Glamourrak eta sona handiak hainbeste leku hartzen duen bizibidea izanik - eta, aldi berean, lehia handiko eta aukera gutxikoa-, pentsa daiteke lehia horretan toki bat bilatzeko hezi behar ditugula gure ikasleak, hots, oso lehiakor eta indibidualista izateko.

La idea de que el mundo en que vivimos es más bien competitivo puede llevar a pensar que conviene enseñar a los alumnos para que estén preparados para ello, exponiéndoles a grandes dosis de competición. Sin embargo, esta suposición puede ser ciertamente cuestionable. Primero porque hay muchos aspectos del mundo real que son extremadamente cooperativos. (Prieto Navarro, 2007, 7. or.)

Lehiakortasunaren ikuspegia ez da bazter uztekoa ikus-entzunezkoen sektoreko lanbideetan, baina mundu profesionaleko egunerokoan, errealitatean, lankidetzan eta norabide berean arraun egiten duen taldean aritu beharko dute ikasleek; horregatik da hain garrantzitsua ikaskuntza aktibo eta kooperatiboetan trebatzea ikasleak, graduko lehen mailetatik hasita.

Esaten ari garen horrengatik guztiagatik ikasgai honi lotutako gaitasunetako bat kontsidera daiteke langintza kooperatiboa bera; izan ere, ikusentzunezko sektorerako heziko ditugun profesionalok talde lanean ez ezik era kooperatiboan ere aritu beharko dute -ikus-entzunezko produktuak egin edo diseinatzen dituztenean - edo, gutxienez, ongi jakin beharko dute 
- sektoreko beste egitekoren batean aritzen direnean ere- zein diren lan egiteko moduak eta baldintzak.

Ikus-entzunezko Komunikazioko Graduaren izaerari erreparatuta, are gehiago IST ikasgaiaren ikaskuntza helburuei, metodologia aktiboek aukera paregabeak eskaintzen dituzte ikasleak beren lanbidea izango den horren lan-errutinetan trebatzeko. Ikasleak Ikaskuntza Kooperatiboan (IK) murgiltzea da erronka garrantzitsuenetako bat IST ikasgaian, baina gainera, Proiektuetan Oinarritutako Ikaskuntza (POI) izango da ardatza.

Hona proiektuetan oinarritutako ikaskuntza (POI) aukeratzeko hainbat arrazoi:

- Nagusiki, ikasleen berariazko premiei erantzutea. Izan ere, gure proposamenaren bitartez, ikus-entzunezko produktuaren sortze, ekoizte eta errealizazioan trebatu nahi ditugu ikasleak.

- Garai bateko ikaskuntzan ez bezala, ikaslearen trebezia-gaitasunak garatzeko baliagarria izango den ikaskuntza eskaini nahi da.

- Ikasleen autoestimua hobetu, eta, batik bat, haien motibazioa sustatzea.

— «Pentsatzen» irakastea: ikaskuntza aktibo eta kritikoa lantzea.

- Ikasleen autonomia eta parte hartzea areagotu eta bermatzea.

Proiektuaren konplexutasuna kontuan izanik, lauhilekoa metodologia desberdinetan sekuentzializatu eta tenporalizatu da: hasteko, Kasuetan Oinarritutako Ikaskuntza (KOI) aplikatuko da; ondoren, Arazoetan Oinarritutako Ikaskuntza (AOI) (Ikus 5.1. puntua eta Taula 2), eta, azkenik, ekingo zaio proiektuari berari. Arian-arian, irakasleak behar adinako argibide teorikoz gidatuko ditu ikasleak kasu eta arazoetan barrena.

Lehen bizpahiru asteetan, KOI metodologian oinarritutako ikaskuntzan barneratuko gara, gelan ikus-entzunezko kasu errealak aztertzen eta lantzen hasita. Autore ezagunen lanak ez ezik, aurreko urteetako ikasleek egindako proiektuak ere ikuskatuko dira. Probetxu handiko ikaskuntza da ikasleek berek egindakoetatik ez ezik, baita beste egile batzuen lanetatik ere ikastea; egile horiek beren parekideak direla jakinda - beste urte batzuetako ikasleak - hobeto irudika dezakete irakasleak zer eskatzen dien IST ikasgaian, zer ikasiko duten, zer egitera iritsi daitezkeen... Ikusiaren gainean ikasteak eta praktikatzeak (ez alderdi teoriko soilak memorizatzeak) onura hauek dakarzkie ikasleei: ideiak eta kontzeptuak hobeto aztertzea eta finkatzea, praktika profesionalerako prestakuntza hobea izatea, talde lanean eta ikaskideekin interakzio sozial egokiak garatzea, eta irakasleak esleitutakoa baino denbora luzeagoan aritzea (Reynolds, 1990).

Ariketa deitu diegun arazoak planteatuko dira ondoren (astean edo bi astean, bat, gutxi gorabehera). Guztiak azken proiektua erdiesteko behar diren ezagutzak barneratzera bideraturik daude, era progresiboan landuz trebetasun teknikoak (Ikus Taula 2). Ikasleak taldeka ariko dira lanean, irakasleak ausaz eratutako taldeetan (deituren arabera, normalean). Irakasleak 
taldeka gidatuko ditu ikasleak, tutoretza orduetan: talde bakoitzak behar dituen jarraibideak jasoko ditu eta talde kooperatiboen martxari erreparatuko zaio. Morales Buenok eta Landa Fitzgeraldek (2004) dioten bezala, ikasleak dakitenaren gainean eraikitzen doaz ezagutza, eta, gainera, beren ikaskuntza prozesuaren monitorizazioa egiten dute. Autore horien arabera, arazoak ebazteko bidean taldetan aritzean, ikasleek beste ikasle batzuen iritziei aurre egiten ikasten dute eta horrek beste galdera batzuk egitera estimulatzen ditu - arazoak ebazteko gaitasun egokia, bestalde - . Horiek dira AOI metodologia erabiltzeak dakartzan onura agerikoenetakoak.

Hala, lauhilekoaren lehen sei-zazpi asteetan ez dituzte soilik trebakuntza teknikoak lortu; taldean lan egiten ohitu dira, lana monitorizatzen eta ebaluatzen saiatu dira, tutoretza saioetan bildu dira... eta horrekin guztiarekin, proiektuari heltzeko bidean jarri dira.

Ikasgaiaren lehen egunetik ikasleek badakite, 4-6 laguneko taldetan banatuta, ikus-entzunezko proiektu «erreal» bat egin behar dutela: hiru-bost minutuko ikus-entzunezko pieza bat. Irakasleek kontuan hartzen dute lehen mailako ikasgaia dela eta ikasleek ikus-entzunezkoetan duten ezagutza oso gorabeheratsua izan ohi dela, baina proiektuek eszenario erreal batean aurkezteko modukoak izan behar dute. Graduaren hasieratik bultzatu ohi dira ikasleak gizarteko ekintzetan parte hartzera, hala nola ikus-entzunezko jaialdi eta sariketetan.

Ikus-entzunezko proiektuari heltzeko langintzan, hona ikasleek bideratzen dituzten egitekoak:

1. Ideien brainstorminga. Sormen prozesuari ekiteko, beharrezkoa da ikasleak beren ekarpenak egiteko libre eta eroso sentitzea. Taldean burutuko duten proiektua aberasteko ahalegina kide guztien egitekoa da, eta hasieratik beretik erakutsi behar dute inplikatuta daudela.

2. Proiektuaren diseinua: gidoiaren zirriborroa, storyboarda eta produkzio plan osoa. Irakaslearen laguntzarekin hasiko dira proiektuari forma ematen.

3. Lokalizazioak eta castinga. Lehen mailako ikasleak izan arren, aktore profesionalekin lan egitera ere animatzen ditugu. Ez da nahitaezko baldintza, baina profesionalekin harremanetan lehenbailehen sartzean, ikasleek dezente hobetzen dute beren buruaren eta ikasketaren autopertzepzio maila.

4. Irudi-soinuen grabazioa.

5. Edizioa.

6. Bideo eta audio postprodukzioa.

Grabazio-edizio-postprodukzioan aritzeko, eskola-ordu presentzialetan ikasten dituzte oinarriak, eta eskolaz kanpoko orduetan landu eta finduko dituzte ikasleek ikus-entzunezko piezak, eskatzen zaien maila teknikoa irits dezaten. 
7. Gelakideen aurrean aurkeztea. Ikasleen komunikazio gaitasunak lantzeari ere lehentasunezkoa deritzogu ikasgai honetan. Lehen mailatik ohitzen ditugu ikasleak euren piezen defentsa egitera jendaurrean.

8. IST Jaialdia: lehen mailako ikus-entzunezko proiektuen artean sailkatutako onenen emankizuna da. Ikasgaiaren fruitua gizarteratzeko lehen saioa da.

Balirudike 4., 5. eta 6. puntuetako egitekoak teknikoki menderatzearekin osatuko litzatekeela ikasgai honetan ikasi beharrekoa. Alabaina, ikus daitekeenez, ikus-entzunezko pieza bat egiteak beste alor askoren ezagutzan sakontzea eta hainbat gaitasun tekniko eta sozial lantzea dakartza.

Jada aipatu dugunez, ikus-entzunezkoetako profesionalen ereduari jarraitu eta sektorearen ibilbidean trebatu nahi badira ikasleak, IST ikasgairako planteatu ohi ditugun proiektuak garatzeko, ezinbestekotzat ikusi da Ikaskuntza Kooperatiboa planteatzea. Ikaskuntza Kooperatiboak esan nahi du taldekideek elkarrekin lan egin behar dutela helburuak lortzeko, eta taldekide bakoitzak burutzen dituen jardueren emaitzak eta lortzen dituen ezagutzak ez direla onuragarriak soilik beretzat, ezpada taldekide guztientzat (Prieto Navarro, 2007). Gainera, lantaldeak helburuak lortzen ditu, soilik eta bakarrik soilik, baldin eta taldekide bakoitzak bere helburuak lortzen baditu (UPM, 2008a, 5 or.).

IST ikasgaian planteatu ohi diren ariketa eta ikus-entzunezko proiektu praktikoen bitartez, ikasleen arteko elkarrekintza areagotu egiten da, eta parte-hartze zuzen eta aktiboen bitartez materiaren ulermenean eta ezagutzan sakontzen dute ikasleek, bai proiektuen prestakuntzaren beraren alorrean, baita kideekiko komunikazio gaitasunetan ere. Bestela esanda, gaitasun espezifiko eta zeharkakoak landu eta garatzen dituzten metodologietan ari gara lanean.

Aspaldi jakinarazi zituen Panitzek (1999) ikaskuntza kooperatiboaren onurak, eta hiru motatan sailkatu zituen: onura akademikoak, sozialak eta psikologikoak. Autoreak egindako sailkapen zehatzetik, honako hauek nabarmendu nahi ditugu IST ikasgaiaren ikaste-irakaste prozesuan:

- Egoerak eta jarduerak beste ikuspuntu batetik ikustea sustatzen du.

- Metakognizioa sustatzen du, eta ikasleek jarduera kontrolatzen duten bizipena dute (onura akademiko gisa ulertuta).

- Ikasleek aginte gaitasuna garatzeko eta praktikatzeko giroa ahalbidetzen du (onura sozial gisa ulertuta).

- Ikaskuntzaren esperientziak ikasleen asebetetze maila areagotzen $\mathrm{du}$, eta, era berean, haien antsietatea murrizten du nabarmen (onura psikologiko gisa ulertuta). 


\section{IST IKASGAIAN AGINTZEN DUTEN PRINTZIPIO DIDAKTIKOAK}

Unibertsitateko ikaskuntzari begira Herranek (2011) egindako ezaugarri didaktikoen zerrenda erreferentziatzat hartuta, hona gure metodologiaren gidalerroak:

- Leku-denborazko ingurunea eta ikasle kopurua egokitzea. IST bi espazio nagusitan lantzen da: ohiko ikasgela arruntak (klase magistraletarako) eta laborategi multimedia (ikasleak 4-6ko lantaldetan antolatu ohi dira). Gainera, ikus-entzunezko piezen lokalizazioak egiteko, ikasleak Fakultateko eraikinetatik kanpo aritzera bultzatzen dira hasierako lanetan, campusean bertan - bestelako argi eta soinu baldintzak lantzeko - , eta gero, azken proiektuari begira, diseinatu duten ikus-entzunezko piezari doituko zaion espazioak bilatzera, batik bat unibertsitateko eremuetatik kanpo.

- Parte hartze aktiboa eta ikasleen asebetetzea sustatzea. Urtero ohartu gara ikasleen arteko lan giroa positiboagoa dela «gustatzen zaiena» egiten dutenean. Gustuko lanak eta gustuko taldeek berebiziko eragina dute azken emaitzan.

- Produktibo ez ezik, sortzaile ere izatea. Ikasgai honetan ikus-entzunezko piezak sortzen dituzte ikasleek: beren eta ikaskideen sorkuntza lanak kritikoki aztertzera bultzatzen ditugu ikasleak.

- Autoikaskuntzaren kontzientzia hartzea. Ikasleak beren ikaskuntza prozesuaren jabe izatea nahi dugu: helburua da ohartzea ezagutzan eta praktika errealean aurrera egiten dutela eta lantalde kooperatiboetan lan egitea aberasgarria dela guztientzat eta bakoitzarentzat.

- Ikasgelako eta laborategietako ikaskuntza errealitatera hurbiltzea. Ikasturte amaieran Fakultateak antolatu ohi duen IST Jaialdiaren helburuetako bat ikasleak egoera errealean kokatzea da: sariketa batean parte hartzeak, oinarriak onartzea eskatzen du eta gelako ikaskideen hautapenean sailkatua izatea.

\section{NOLA PLANIFIKATU DUGU IST IKASGAIA?}

Gorago esan dugun bezala, IST ikasgaia Komunikazioaren arloko ikasle guztiek egiten dute EHUn, eta, horrenbestez, lehen modulu-mailari lotutako ikaskuntza emaitzak lortzeko helburuz planifikatu da. Ikasle askok Ikus-entzunezko Komunikazioko Gradua amaituko dute, eta, ordurako, Produkzio eta Errealizazio materian lortu behar dituzten gaitasunak ere begien aurrean jarrita daude, hemen dagokigun ikasgaian.

Ikus-entzunezko Sormen Teknikak - bigarren lauhilekoko ikasgaia izanik - segida ematen dio lehen lauhilekoan Ikus-entzunezko Hizkuntza 
ikasgaian ikasitakoari, eta praktikan jartzen dira han hartutako ezagutza estetikoak, beti ere, ikus-entzunezko proiektuak gauzatzeko behar diren gaitasun teknikoak landu eta erabiliz.

Bigarren mailatik aurrera hasten dira ikasleak beren komunikazio graduan sakontzen. Ikus-entzunezko Komunikazioko Graduari dagokionez ere, hirugarren eta laugarren mailan biltzen dira alorreko ikasgai gehienak, bai derrigorrezkoak (ikus Taula 1), bai hautazkoak (Bideosorkuntza, Audio postprodukzioa, Diseinu grafikoa eta Multimedia...):

1. taula

Ikus-entzunezko Komunikazioko Graduan ISTri lotutako derrigorrezko ikasgaiak

\begin{tabular}{lll}
\hline \multicolumn{1}{c}{ 2. maila } & \multicolumn{1}{c}{ 3. maila } & \multicolumn{1}{c}{ 4. maila } \\
\hline - Ikus-entzunezko Narra- & - Gidoia I: Fikzioa & - Produkzioaren Kudea- \\
tiba & - Gidoia II: Fikzioz & keta \\
- Ikus-entzunezko Sor- & bestekoa & - Irrati Produkzio eta \\
men Prozesuak & - Errealizazioa I & Errealizazioa \\
& - Errealizazioa II & \\
\hline
\end{tabular}

Ikus-entzunezkoen munduan ohituak egonagatik ere, ikasle gehienak IST ikasgaian hasten dira material profesionala erabiltzen produkzio fasean (bideo eta audio grabaziorako, ediziorako softwarea...), eta ulertzen zer esan nahi duen sektorearen barruan ere: ikus-entzunezkoaren osotasunaren azpian, lanbideko hainbat alor bereizten baitira eta parte hartzen baitute (gidoia, produkzioa, zuzendaritza, errealizazioa, edizioa...).

\subsection{IST-ko ikaskuntza emaitzak}

Oro har, ikasgai hau gainditzeko, ikasleek erakutsi behar dute:

1. Ezagutzen dituztela bideo kameren ezaugarri optikoak, elektronikoak eta erabiltzeko moduak, eta praktikan ongi baliatzen dituztela.

2. Behar bezala aplikatzen dituztela hainbat ingurunetan soinua grabatzeko eta editatzeko oinarrizko ezagutzak.

3. Edizio ez-linealeko oinarriak ongi menderatzen dituztela.

4. Ikus-entzunezko proiektu unikamerak diseinatzeko gauza direla, eredu profesional oinarrizkoari jarraiki.

Lauhilekoaren hasieratik, ikasleak jakinaren gainean daude zer-nolako ikus-entzunezko piezak egingo dituzten: Ikasle Gidan zehaztu dizkiegu ikasgaiari dagozkion lan-jarduera guztiak, epeak, eta ebaluazio sistema. 
Ikasgaiaren helburuak lortu eta goian adierazitako ikaskuntza emaitzak eskuratzeko, artikulu hau sinatzen dugun irakasleok hainbat jardueraz osatutako egitaraua antolatu ohi dugu IST ikasgaian. Ikaslea parte hartzearen garrantziaz ohartarazten da etengabe, eta, batik bat, taldean ari denean, ikaskideekiko konpromisoa azpimarratzen zaio, benetako inplikazioz eta ekimenez hel diezaion lanari (Paricio, 2010).

Ikaskuntza bideratzeko, honako jarduera mota hauek landu eta garatu ohi dira:

A) Eskola magistralak. Eskola teorikoak galdera-giden bidez abiatu ohi dira. Ikus-entzunezko Hizkuntza ikasgaiaren kontzeptuak gogoan hartu - eta behar izanez gero, errepasatu - , eta ikuspegi teknikotik lantzen dira, bereziki alderdi teknikoari erreparatuta.

B) Kasu azterketak. Aurreko ikasturteetako ikasleek ekoitzitako ikus-entzunezko piezak erakusten eta aztertzen dira, ikasleek irudika dezaten noraino hel daitezkeen beren lanarekin. Izan ere, irakasleok nabaritu dugunez, ez bazaizkie eskaintzen, jarrera itxia eta uzkurra erakusten dute hainbat ikaslek, eta zail egiten zaie beren trebetasun-gaitasunetan sinestea.

C) Arazoak ebaztea. Ikus-entzunezko pieza oso bat hartzen da abiaburutzat, eta haren azterketa egin ondoren, irakasleak hiru ariketa praktiko proposatuko ditu (Ariketa 1, Ariketa 2, Ariketa 3): zailtasun maila areagotuz doa batetik bestera, bai errutina profesionalei dagokienez, bai gidoi literario-teknikoen erredakzioari dagokionez ere. Gidoi literario eta teknikoen erredakzioa oso neurri apalean lantzen da lehen mailan. Kontuan izan behar da, Gidoigintza hirugarren mailako ikasgaia dela.

D) Proiektuaren diseinua eta azalpena. Ikasleek ikus-entzunezko pieza libre bat proiektatu eta sortu behar dute, 3-5 minutuko iraupena izango duena. Lantalde bakoitzak bere interes propioari eta bere motibazioari helduko dio: xehetasunak planifikatu, taldekideen artean lan-rolak banatu, eta proiektua bideratzeko materiala hautatuko dute kideen artean. Irakasleak prozesuaren eta taldekideen parte-hartzearen jarraipena egiteko tutoretzak antolatuko ditu, nola prozesua ongi bideratu eta ikaskuntzan hobekuntzak ezartzeko, hala ikus-entzuneko pieza behar bezala osatzeko.

E) Lan-jardueren azalpena. Taldean burututako lanak azaltzen dituzte ikasleek (Ariketa 1, Ariketa 2, Ariketa 3): jarduera honek gogoetarako beta eskaintzen die ikasleei, eta ikaskuntzan aurrera egitea ahalbidetzen die azalpenak ematen ari direnei, baita entzuten ari direnei ere. Lauhilekoaren amaieran, lantaldeek gelakideen aurrean aurkeztu beharko dituzte beren piezak, eta, errubrika sistema erabilita, gelako pieza onenak hautatuko dira Fakultateko IST 
Jaialdian aurkezteko. Lehen mailako gela bakoitzetik bi-hiru pieza aurkezten dira: 12-15 lan, urtero.

Ikus-entzunezko lanak hautatzeko baliatuko den errubrikak irakasleak ebaluaziorako baliatuko duenaren irizpide nagusiak jasotzen ditu. Honela osatu ohi da IST Jaialdiko epaimahaia: Fakultateko irakasle bat edo bi, Ikus-entzunezko Komunikazioko laugarren mailako bi ikasle eta euskal ikus-entzunezkoen sektoreko pertsona ezagun bat edo bi.

\section{IST IKASGAIAREN EBALUAZIOA} 23. or.):

Ebaluazioari dagokionez, Paricioren iritziari lotu gatzaizkio (2010,

El proceso de evaluación debe valorar, estrictamente, el grado de logro de los resultados de aprendizaje previstos para la asignatura. El estudiante puede demostrar esos resultados de aprendizaje aportando unas realizaciones terminadas (un trabajo, un examen, un proyecto, etc.) o sometiendo a observación el propio proceso de realización de algo.

Ikasgai honetan, ebaluazio jarraitu formatiboa eta sumatiboa ardatz izango dira. Alegia, ikasleek, batetik, ikaskuntza emaitzak erdietsi beharko dituzte, eta horretarako jarritako ebaluazio irizpideak gainditu. Bestetik, ikasgaiarekin helburu hartutako gaitasunen lantze eta garatze bidea ebaluatzea komeni da; hots, ikasleek beren burua etengabe gainditzeko prozesua bera (UPM, 2008b; Villardon Gallego, 2006).

ISTko irakasle gisa izan dugun esperientzian frogatu ahal izan dugunez, bi alderdi hauek izan behar dira kontuan: bai burura eramandago lanak, bai lan prozesuaren behaketa eta gogoeta. Ikasle gehienek, baina, lantalde kooperatiboan aritzeko eskarmentu nahikorik ez dute, eta ikaskuntza prozesu gisa ulertzea ere asko kostatzen zaie. Imbernon Muñozek eta Medina Moyak (2008) ere jakinaren gainean jarri gaituzte, ikasleen parte hartzearen zailtasunez mintzatu zaizkigunean.

Hala ere, irakasleok lantaldean aritzearen garrantzia azpimarratu ohi diegu ikasleei eta ikasgai honetako lan errutinak barneratu beharraz jakinarazi zaie behin eta berriro, halaxe lan egin beharko baitute etorkizunean komunikazioaren arloko profesional gisa.

Beste alde batetik, IST ikasgaiaren ikaskuntza-irakaskuntzak berekin dakar -inplizituki zein esplizituki - lanaren gaineko gogoeta, bakarkakoa eta taldekoa. Etengabe azpimarratzen diegu ikasleei, lanean ari direnean - taldeka zein bakarka-, kritikoki begiratzeko ohitura hartu behar dutela, arian-arian esku artean duten ikus-entzunezkoa zuzendu eta aurrera egiteko. Zalantzan jarri behar dituzte etengabe hartzen dituzten erabakiak: grabazioan, irudiari eta soinuari buruzkoak, edizioan, etab. 
Ikasgaian planteatutako jarduera eta lanak gauzatu ahala, eta ebaluazio jarraituari esker - batik bat, formatiboa-, ikasleak ikaskuntza emaitzak lortzen doaz. Irakasleak lauhilekoaren hasieratik tutorizatzen eta bideratzen ditu ikasleen prozesu guztiak. Tutoretza saioak dira, hain zuzen, lantaldeen kooperazio frogak jasotzeko biderik zuzenena.

2. taula

IST ikasgaiaren ebaluazio-sistema

\begin{tabular}{|c|c|c|c|}
\hline \multicolumn{2}{|r|}{ Ebaluazio-tresnak } & Ebaluazio-irizpideak & $\begin{array}{c}\text { Notaren } \\
\%\end{array}$ \\
\hline 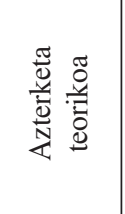 & $\begin{array}{l}\text { - Testak } \\
\text { - Galdera laburrak } \\
\text { - Garatzeko galderak }\end{array}$ & $\begin{array}{l}\text { - Erantzun zuzenak eta argiak. } \\
\text { - Kontzeptuen koherentzia eta } \\
\text { zehaztasuna. } \\
\text { - Eduki teorikoak eta praktikoak } \\
\text { lotzen jakitea. }\end{array}$ & $\% 40$ \\
\hline \multirow{3}{*}{ ö } & Ariketa 1 & $\begin{array}{l}\text { - Irudiak eta soinuak grabatzea, } \\
\text { ereduei jarraiki. } \\
\text { - Denbora kodeak (TC) hartzea eta } \\
\text { ez etetea grabazioan. } \\
\text { - Lan-errutinez eta -ordenaz jabe- } \\
\text { tzea eta bereganatzea. }\end{array}$ & $\% 2,5$ \\
\hline & Ariketa 2 & $\begin{array}{l}\text { - Aurreko irizpideei eustea. } \\
\text { - Giro-soinua hartzea. } \\
\text { - Raccorda eta ardatza zaintzea. }\end{array}$ & $\% 5$ \\
\hline & Ariketa 3 & $\begin{array}{l}\text { - Aurreko irizpideei eustea. } \\
\text { - Edizio ez-linealaren hastapenak. } \\
\text { - Bideo- eta audio-postprodukzioa- } \\
\text { ren hastapenak: kolore-zuzenketa, } \\
\text { trantsizioak, efektuak, grafismoak. } \\
\text { - Istorioa eraikitzea: zer kontatu } \\
\text { nahi dugu? Nola kontatuko dugu? }\end{array}$ & $\% 7,5$ \\
\hline $\bar{\circ}$ & Proiektua & $\begin{array}{l}\text { - Aurreko irizpide guztiei eustea. } \\
\text { - Edizio ez-linealean eta bideo- eta } \\
\text { audio-postprodukzioan sakon- } \\
\text { tzea. }\end{array}$ & $\% 40$ \\
\hline 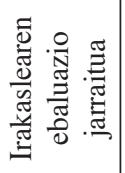 & Talde-tutoretzak & $\begin{array}{l}\text { - Lanen gaineko gogoetak egitea. } \\
\text { - Zailtasunei aurre egiteko jarrera. } \\
\text { - Taldean izandako inplikazioa. } \\
\text { - Jarraitutasunez lanean aritu izana. }\end{array}$ & $\% 5$ \\
\hline
\end{tabular}


Azken eskola egunean, ikaskuntza helburuak kontuan hartuta, autoebaluazio eta koebaluazio fitxak betetzen dituzte ikasleek. Autoebaluazio eta koebaluaziorako atondu ditugun galdetegietan, ikasleek 1etik 10era bitarteko puntuak emanez balioetsi behar dituzte beren aurrerabideak, alor hauetan: irudien eta zuzeneko soinuaren grabazioan, kapturan eta inportazioan, edizioan, eta ideiei zein sormenari lotutakoetan.

Horiez gainera, ikasgaiaren ebaluazio globala egitera gonbidatzen ditu irakasleak. Galdetegia kualitatiboa da batik bat, anonimoa eta ikaslearen ebaluazioan eraginik ez duena: aukera ona da irakasgaiaren planteamenduari buruzko iradokizunak egiteko, zeinak oso onuragarriak baitira irakaslearentzat bere irakaslana hobetzeko. Lauhilekoan landutako gai zehatzak puntuatzeaz gain, gehien eta gutxien gustatu zaizkien alorrei eta hobetzekoei buruzko iritzia eskatzen da.

\section{BERRITZE PROZESUAREN LEHEN BALORAZIOA}

Euskal Herriko Unibertsitateak ikasgaiak eta ikaskuntza-prozesuak ebaluatzeko aukera eskaintzen die ikasleei lauhilekoaren amaieran. Informazio hori oso baliagarria da komunitate akademikoarentzat; baita irakasle bakoitzarentzat ere.

Guri dagokigunez, bi eratako ebaluazioa jaso ohi dugu IST ikasgaian:

- Kuantitatiboa: Unibertsitateak Irakaslana Ebaluatzeko Zerbitzuaren bitartez (SED/IEZ) diseinatutako galdetegi itxia: ikasleek ikasgaiaren amaieran bete ohi dute, eskolak amaitzeko bi aste falta direla.

- Kualitatiboa: Aurreko atalean aipatu dugun bezala, azken eskola egunean egindako saioa da. Batetik, irakasgaiaren gaiei eta prozesuei lotuago dagoen galdetegi zehatzagoa bilatzen dugu irakasleok. Bestetik, ikasleek beren ikaskuntza prozesuaz duten ikuspuntua eta gogobetetzeaz mintzatzeko aukera dute. Bide honek datu esanguratsuagoak eskaini ohi dizkigu gure jardueraren premiak eta ahuluneak detektatzen lagundu, eta, ondo bidean, hurrengo ikasturterako, gure irakaskuntza metodoak zuzendu eta hobetzeko.

Gure esperientzia laburra izan arren, 2014-2015eko ikasturtean ere honako emaitzak berretsi ditugu. Hauxe diote ikasleek:

1. IST ikasgaian lantzen diren kontzeptu teorikoetako batzuk emanak dituztela jada aurreko lauhilekoan, Ikus-entzunezko Hizkuntza ikasgaian. Ikuspegi teorikoa lehendik nahikoa landurik ikusten dutenez, IST praktikoagoa izatea hobetsiko lukete: eskola magistralak gutxitu eta praktika orduak gehituta.

2. Erreparo handia jartzen diete taldean lan egiteari: talde lan kooperatiboa oso eskasa dela aitortzen dute, eta banakoen parte hartzea 
taldeetan oso gorabeheratsua: batzuen guztizko apatiaren eta beste batzuen erabateko inplikazioaren artean. Azken notak kezkaturik, banakako lan gehiago eskatzen dute.

3. Ez dira oso objektiboak gelakideen piezak analizatzeko orduan: normalean, autobalorazio oso positiboa egiten dute, baina oso kritikoak dira ikaskideekin.

4. Dezente kostatzen zaie lan-errutinak onartzea eta barneratzea: oraindik ez dira ohartzen ikaskuntza prozesua lan munduan aritzeko bideratuta dagoela. Lehendik zekitena jakitearekin konformatzen dira batzuetan.

Irakasleok, ostera, iritzi hau dugu:

1. Oro har, lauhilekoaren hasieran zekitenarekin alderatuta, jauzi handia ematen dute ikasleek, nahiz eta berak ez diren gehiegi ohartzen horretaz.

2. Hobeto egokitu behar dira Ikus-entzunezko Hizkuntza (lehen lauhilekoa) eta Ikus-entzunezko Sormen Teknikak (bigarren lauhilekoa) ikasgaiak.

3. Ez dator bat Boloniarekin, ez izaera hain praktikoa duen IST ikasgaiarekin, sei ikasleko edo seitik gorako lantaldeetan banatzea ikasgelak. Fakultateak laborategiko orduetarako ikasle-banaketari erreparatu beharko lioke, kalitatezko ikaskuntza bermatze aldera.

4. ISTko irakasle guztien artean, gogoeta serio eta eragingarria egin beharko lukete ikasgaian metodologia aktiboak nola ezarri erabakitzeko.

\section{ESPERIENTZIARI BURUZKO HAUSNARKETA ETA AURRERA BEGIRAKOAK}

Ikaskuntza Kooperatiboa, arrakastatsua izango bada, oinarrizko bost elementu hauetaz osatzen da (Johnson, Johnson eta Holubec, 1999): interdependentzia positiboa, banakoen erantzukizuna, aurrez aurreko interakzioa, pertsonarteko eta talde laneko gaitasunak, lanaren gaineko gogoeta.

Hona, puntuz puntu, gure hausnarketa IST ikasgaian izan dugun esperientziari lotuta:

- Interdependentzia positiboa. Irakasleok hasieratik aurkeztu diegu ikasleei zein den beren egitekoa: argi eta garbi adierazi zaizkie ariketen eta proiektuaren nondik norakoak. Taldeko kideen artean interdependentzia positiboa gertatzen denean, banako bakoitzak sentitzen du bere lana garrantzitsua dela azken lana arrakastaz burutzeko. Lantaldeko kideek, orduan, norabide berean egiten dute arraun: kide bakoitzak bere helburuak lortzen ditu, eta gainerako lankideek berenak lor ditzaten parte hartzen du. 
- Banakoen eta taldearen erantzukizuna. Kide bakoitzak bere erantzukizunak onartzen ditu, eta taldeak, osotasun gisa, esku artean duen lana burutzeko konpromisoa hartzen du. Inork ez du txandapasa egiten; bakoitza bere egitekoaz eta taldearenaz erantzule sentitzen da. Osagai hau oso lotuta dago aurrekoarekin: gure eskoletan ikusi dugunez, gorabehera handi samarrak egon ohi dira talde batzuetatik besteetara; izan ere, lehen mailako ikasleak izanik, oraindik ez daude ohituta lantalde kooperatibotan aritzen, edota Bigarren Hezkuntzatik dakarte «esperientzia txarra» den sentsazioa.

Irakasleok tutoretza saioetan bideratzen ditugu talde batzuetan sortu ohi diren gaizki-ulertzeak eta egoera gatazkatsuak. Beti ere, banakoen dohainak nola indartu eta taldeari mesede nola egiten zaion azpimarratuta.

- Aurrez aurreko interakzioa. Talde lana gailen bilakatzen da kideek aurrez aurre jarduten dutenean: elkarri ikasteko aukera paregabea izateaz gain, elkar zoriontzeko eta animatzeko bidea ere bada. Gelakideen aurrean eta irakaslearekin egindako tutoretza saioetan ikasleek egiten dituzten ariketa-proiektuen azalpenetan beste taldeek nola funtzionatu duten ikusten dute, eta beste eredu batzuei erreparatzeko aukeratzat har dezaten saiatzen dira irakasleak.

Gustuko lanean, aldaparik ez dio gure esaera zaharrak, eta nabarmena da horrela aritzen diren taldeek lortzen duten asebetetze maila.

- Pertsonarteko eta talde laneko gaitasunak. Gaitasun sozialak etengabe lantzen dira talde lanean aritzean. Taldea harmonian jardutea izango da helburua, baina aipatu dugunez, gatazkak eta egoera kritikoak ez dira bakanak. Hala ere, beren zailtasun eta guzti, aukera gisa kudeatu behar dira egoera horiek; hala saiatzen gara ISTko irakasleok, profesionalen artean ere talde lanean aritu beharko dutela esanda ikasleei, eta beti azken helburuan jarri behar dela begia, ez norberekoikeria eta jarrera pertsonalistetan.

- Burututako lanaren gaineko gogoeta (autoebaluazioa). Taldearen hobe beharrez, garrantzitsua da gogoeta saioak egitea prozesuak irauten duen denboran: jardute-jarreren alderdi positiboak sustatzen eta hobetu beharrekoak identifikatzen laguntzen diete irakasleek taldeei; ikasleei baliagarria izango zaie etorkizuneko talde lanetan aritzeko gaitasunak sendotzeko ez ezik, baita beren burua eta kideena ebaluatzeko irizpideak beregatzeko ere.

Ikasleengan zentratutako ikaste-irakaste prozesuetan oinarritutako estrategiak erabiltzeak ikaskuntza metodologiko berritzaileak baliatzeko motibazioa izan du irakasleongan ere, irakaskuntzaren kalitatea hobetzeko helburuak bultzatuta beti ere. Hiru urteren buruan lortu dugun esperientziak ondorio hauetara ekarri gaitu: 
- Metodologia aktiboek ahalegin berezia eskatzen digute irakasleoi: hasi aurretik, ikasgaiaren helburuak definitzeko eta planifikatzeko zehaztasuna bilatzen, eta, abiatu ondoren, ikasgaia ongi bideratzen, ikasleak etorkizunerako baliagarri izango dituzten gaitasun profesionaletan trebatzen has daitezen.

- Emaitza on edo bikainak lortzeko, metodologia aktiboak taldeetara egokitu behar dira: taldeen tamainak eta ikasle motak zerikusi handia izango dute ikasgaiaren garapenean. Aldez aurretik ezarritako helburuak eta egindako planifikazioa oinarri izango dira ikasgaian abiatzeko, baina irakasleak taldeetara moldatzeko jarrera erakutsi behar du, eta egin behar diren doikuntzak egiten ahalegindu.

- Emaitza gorabeheratsuak lortu izan ditugun arren, metodologia aktiboekin ikasleak beren ikaskuntza-irakaskuntza prozesuetan esku hartzera bideratuak daudenez, haien motibazioa pizteko baldintza eta jarduera «errealak» sortzen jarraitu behar dugu (Fakultatean antolatutako IST Jaialdia, esaterako), eta gure inguruan antolatu ohi diren jaialdi-sariketetara aurkezteko moduko ikus-entzunezko piezak sorrarazten (Gaztezulo, Huhezinema, Zinebi Express, etab.).

- Unibertsitateko webgunean argitaratutako irakaskuntza gidaz haratago, ikasleentzat ikaskuntza gida prestatzeko ohitura zabaldu beharko genuke ISTko irakasleon artean: ahalik eta osatuena, ikaskuntza emaitzak eta ebaluazio irizpideak ongi finkatuak dituena. Ez da egiteko makala hau, kontuan harturik ikasgaiek ez dutela irakasle talde finkorik (urterik urte aldatuz joan da), eta, gainera, irakasle taldea bera ere nahiko zabala dela (8-10 irakasle).

- Metodologia aktiboek ikasle guztientzako aukera eskaintzen dute, adina, ikas maila edo ezagutza maila gorabehera. Lehen mailako ikasgaietan ongi bideratzen ikasiz gero, bidearen erdia egina izango dute Ikus-entzunezko Komunikazioko ikasleek hirugarren mailan Produkzio eta Errealizazio arloko ikasgaietan hasterako. Izan ere, lantalde kooperatiboetan aritzea gaitasun profesionaletara hurbiltzeko jauzi ezinbestekoa baitute ikasle horiek. Horregatik, irakasleok etengabe azpimarratzen diegu ikasleei talde lanean aritzea zein garrantzitsua den.

Beste ikasgai eta materia batzuetarako bezalaxe, ikus-entzunezko ikasgaietan ere ezinbestekoa dirudi ikaskuntza erakundearen bermea izatea - gure kasuan EHUrena - metodologia horiek ezartzeko; horretarako, batetik, baliabide pertsonal eta materialak eskolan eta eskolaz kanpoko jardueretan egoki kudeatzeko bideak jarri behar ditu erakundeak, eta bestetik, esperientziak partekatzeko guneak atondu behar ditu: nola irakasle eta akademiako kideen artean, hala sektore prefesionaleko beste eragile aktiboekin.

Irakaskuntzaren praktika asko aldatu da metodologia aktiboekin, eta urteotako IST ikasgaiko esperientziek erakusten digutenez, etorkizuneko 
profesionalen ezagutza, trebezia eta gaitasunak asko hobetzeko bidean gara, gure unibertsitateak beretzat duen egitekoari dagokion ildoan: «Unibertsitateari dagokio inguruan gertatzen denarekiko pertsona kontziente eta sentiberak heztea, etengabeko eraldaketei doitzeko gai direnak eta arazo berriei modu sortzaile eta etikoan erantzuteko gai izango direnak» (Titulazio ofizialen garapen curricularreko Oinarrizko Dokumentua, 2010eko apirilean onartua).

Unibertsitateak profesionalak trebatu eta zientzia-teknologiak sortu eta sustatzen dituenez, erronka handia du aurrean. Guri dagokigunez, horrek hauxe esan nahi du: etorkizuneko profesional gaituak hezibidean jarri eta gizarteari gazte ekintzaile, sortzaile eta kritikoak eskaini behar dizkiogula, ezagutza tekniko-teknologikoetan oinarri sendoa dutenak, ikus-entzunezko proiektu eta programak sortu eta kudeatzeko gai direnak, eta gure gizarteko kultura, hezkuntza, eta ekonomiaren sektoreetan eragiteko.

\begin{abstract}
In the Audiovisual Communication Degree course run by the UPV/EHU-University of the Basque Country, the subject Audiovisual Creativity Techniques (IST) is the cornerstone in the Production and Technical Direction Module and is given during the first year of the communication degree. The nature and aims of the subject inevitably lead to implementing the Project-based Learning Model (PBL): at the end of the semester the students are required to create and prepare a three to five-minute audiovisual sequence. The audiovisual sequences need to be of a sufficient quality to be presented at the IST Festival organised by the Faculty itself. The learning process in this subject is based on the steps that are followed in the audiovisual sector, and the aim is to accustom the students to and train them in the routines followed by professionals. So despite it being conceived as a pragmatic subject, knowledge of the theoretical aspects needed to produce audiovisual sequences has not been neglected: assessing the technical criteria and reflecting on them are also essential in the IST learningteaching process.
\end{abstract}

Key words: Production and Film making. TV/radio personnel training. Co-operative education. Project-based learning. University education. 
La asignatura de Técnicas de Creación Audiovisual que se imparte en la Universidad del País Vasco (UPV/EHU) es fundamental dentro del módulo de Producción y Realización. Es una asignatura de primer curso, en todos los grados de Comunicación. Su propio carácter y objetivos nos obligan casi indefectiblemente a plantear un modelo de Enseñanza Basada en Proyectos (EBPy), ya que al finalizar el semestre los y las estudiantes deben presentar una pieza audiovisual de entre tres y cinco minutos de duración. Las piezas audiovisuales deben tener la calidad suficiente como para ser presentadas al Festival de TCA, que organiza la Facultad de Ciencias Sociales y de la Comunicación de la UPV/EHU. El proceso de enseñanza se basa en las fases/etapas seguidas en el sector audiovisual, y el objetivo es conseguir que el alumnado se impregne de las rutinas y métodos de trabajo de los profesionales. Ello no es óbice para que aunque se plantee una asignatura pragmática, se menosprecie el aspecto teórico, tan necesario para trabajar el audiovisual: a nuestro entender es indispensable en el proceso de enseñanza-aprendizaje de TCA que los estudiantes valoren los criterios técnicos y así sean capaces de reflexionar y profundizar sobre los aspectos que atañen al conjunto de las obras audiovisuales.

Palabras clave: Producción y Realización audiovisual. Formación de personal de radio/TV. Enseñanza cooperativa. Enseñanza basada en proyectos. Enseñanza universitaria.

L'unité d'enseignement Techniques de Création Audiovisuelle (TCA) que l'on enseigne à l'Université du Pays Basque (EHU/UPV) est fondamentale dans le module de Production et Réalisation. C'est une matière de première année, à tous les degrés de l'enseignement des Sciences de la Communication. Son propre caractère et ses objectifs nous mènent nécessairement à établir un modèle d'Enseignement Basé sur des Projets (EBP) : à la fin du semestre, les étudiant(e)s doivent présenter un travail audio-visuel d'une durée de trois à cinq minutes. Ce travail doit atteindre une qualité suffisante pour pouvoir être présenté au Festival de TCA, organisé par la Faculté des Sciences Sociales et de la Communication de l'EHU/UPV. Le processus d'apprentissage de cette matière est fondé sur les différentes étapes suivies dans le secteur de l'audiovisuel, et son objectif est que les étudiant(e)s acquièrent les habitudes et les méthodes de travail des professionnels. Toutefois, le fait d'avoir envisagé cette unité d'un point de vue pragmatique n'implique pas que nous sous-estimions son aspect théorique, absolument nécessaire pour travailler dans l'audiovisuel : à notre avis, dans le processus enseignement-apprentissage de l'unité TCA, il est indispensable que les étudiant(e)s tiennent compte de l'importance des critères techniques et qu'ils soient ainsi capables de réfléchir sur les différents aspects concernant l'ensemble des travaux audiovisuels. 
Mots-clé: Production et Réalisation audiovisuelles. Formation du personnel de radio/TV. Enseignement coopératif. Enseignement fondé sur des projets. Formation universitaire.

\section{ERREFERENTZIAK}

ANECA (2015). Libro Blanco. Títulos de Grado en Comunicación. Madril: Agencia Nacional de Evaluación de la Calidad y Acreditación.

Eusko Jaurlaritza (2003). Libro Blanco del Sector Audiovisual en Euskadi. Eusko Jaurlaritza.

Fernandez, I. eta Alkorta, I. (2014). El aprendizaje activo como reto: razones visibles e invisibles de una política de desarrollo docente en la UPV/EHU. In Guisasola, J. eta Garmendia, M. (Ed.) (2014), Aprendizaje basado en problemas, proyectos y casos: diseño e implementación de experiencias en la universidad. Bilbo: Euskal Herriko Unibertsitateko Argitalpen Zerbitzua. 1329 or.

Guisasola, J. eta Garmendia, M. (Ed.) (2014). Aprendizaje basado en problemas, proyectos y casos: diseño e implementación de experiencias en la universidad. Bilbo: Euskal Herriko Unibertsitateko Argitalpen Zerbitzua.

Guisasola, J. eta Garmendia, M. (2014). El programa ERAGIN de formación en metodologías activas de la UPV/EHU. In Guisasola, J. eta Garmendia, M. (Ed.) (2014), Aprendizaje basado en problemas, proyectos y casos: diseño $e$ implementación de experiencias en la universidad. Bilbo: Euskal Herriko Unibertsitateko Argitalpen Zerbitzua. 31-87 or.

Herrán, A. de la (2011). Técnicas didácticas para una enseñanza más formativa. In Álvarez Aguilar, N. eta Cardoso Pérez, R. (Koord.), Estrategias y metodologías para la formación del estudiante en la actualidad. Camagüey (Cuba): Camagüeyko Unibertsitatea.

Imbernon Muñoz, F. eta Medina Moya, J.L. (2008). Metodología participativa en el aula universitaria. La participación del alumnado. Bartzelona: ICE eta Ediciones Octaedro.

Johnson, D.W., Johnson, R.T. eta Holubec, E.J. (1999). El Aprendizaje cooperativo en el aula. Buenos Aires: Paidós.

Larrañaga, J. (2012). Convergencia mediática en Euskal Irrati Telebista (EITB). Bilbo: Euskal Herriko Unibertsitateko Argitalpen Zerbitzua.

Morales Bueno, P. eta Landa Fitzgerald, V. (2004). Aprendizaje basado en problemas. Theoria, 13, 145-157 orr.

Panitz, Theodore. (1999). The Case for Student Centered Instruction Via Collaborative Learning Paradigms. ERIC. http://eric.ed.gov/?id=ED448444. 2015eko urriaren 9an kontsultatua.

Paricio Royo, J. (2010). Un modelo de guía docente desde los resultados de aprendizaje y su evaluación. Zaragoza: Instituto de Ciencias de la Educación, Universidad de Zaragoza.

Prieto Navarro, L. (2007). El aprendizaje cooperativo. Madril: PPC editorial. 
Reynolds, J.I. (1990). El método del caso y la formación en gestión. Valentzia: Ediciones del IMPIVA.

Universidad Politécnica de Madrid (UPM) (2008a). Aprendizaje Cooperativo. Madril: Servicio de Innovación Educativa.

Universidad Politécnica de Madrid (UPM) (2008b). Aprendizaje Orientado a Proyectos. Madril: Servicio de Innovación Educativa.

Villardon Gallego, L. (2006). Evaluación del aprendizaje para promover el desarrollo de competencias. Murcia: Educatio Siglo XXI, 24. 57-76 orr. 